\title{
Motive as Transhistorical Phenomenon in the Story of the Adyghe-Russian Bilingual-Educator of the Nineteenth Century Khan Girey "Circassian Legends"
}

\author{
A.M. Kaziyeva, A.A. Pliss \\ Pyatigorsk State University \\ 9 Kalinin Ave., Pyatigorsk, 357532, Stavropol Territory, Russian Federation
}

The article presents the study of the motive structure of the "Caucasian text" in the works of the North Caucasian literature of the first half of XIX. The following task is defined: to determine the motives specific for the "Caucasian text" of the North Caucasian literature.

During the period of national recovery associated with the Decembrist movement, literature was supplemented by a number of works about the Caucasus, written by talented and educated mountaineersCaucasians, such as Sultan Khan Girey, Sultan Kazy Girey, Adil Girey Keshev, Costa Khetagurov, etc. There was a whole literary tradition, which not only poetized the Caucasian world, but also tried to study it ethnographically.

The relevance of the article is also connected with the fact that the Caucasian motifs are easily read both in the works of authors writing in Russian, for whom this region is a historical homeland, and Russian writers, gravitating in their own artistic preferences to a variety of trends and stylistic principles from romantic to postmodern. For some of them, interest in the motives of the Caucasus is determinative for all the creative work. The scientific novelty of the article is that the author for the first time made an attempt to consider the motives typical for the works of Russian and North Caucasian literature about the Caucasus in the context of dialogue of the cultures.

Key words: motivic structure, national culture, image of the world, traditional consciousness, world view, cultural values, Caucasian-Russian bilingualism, dialogue of cultures

\section{Introduction}

The relations between the peoples who inhabit Russia, expressed in the cultural and historical paradigm are a long process. At various stages, it includes the dividual development of any spatial-ethnic unit and full interrelation at the cultural and sociohistorical levels.

At this stage, Russian modern culture and the Caucasian geopolitical space are in a state of spiritual alienation. And every year it becomes wider. Nevertheless, it is the Caucasian literature and culture that the Russian literary tradition has been addressing to for centuries in search of new images, themes, motives and plot collisions.

In both native and foreign literary studies, motive is one of the constantly discussed and controversial categories. Hypotheses of how to structure, type, categorize invariants and variants of this concept are constantly developing, new ideas appear. Some Researchers put forward their hypotheses, others refute them in their works, but, nevertheless, new 
directions in the research activities of literary critics on this issue and the concept of «motive» appear.

Our work, first of all, is based on the definition of this concept, which was proposed by B.M. Gasparov. Under the motive, he proposes to understand "any phenomenon, any semantic "spot" - an event, a character trait, an element of landscape, any object, a spoken word, paint, sound, etc.; the only thing that determines the motive, according to B.M. Gasparov, is its reproduction in the text, so unlike the traditional narrative, where it is more or less certain in advance what can be considered discrete components ("characters" or "events"), there is no given "alphabet" - it is formed directly in the expansion of the structure and through the structure" [1. P. 189].

According to B.M. Gasparov, in this case it is necessary to focus on the principle of intertextual analysis, which allows to combine the concepts of leitmotif and motive: "Such principle is meant, under which motive, appearing once, is then repeated many times, thereat acting each time in the new version, new shape and in all new combinations with other motives" [1. P. 235]. This implies the conclusion that the motive can consist of other motives. This means that the structure of a work is a network of interrelated motives. This universality of the approach to the concept allows us to study the deep structure of the text and expand the boundaries of its analysis and perception.

In the classification proposed by B.M. Gasparov, our attention was drawn to the motives that are specific for the Russified "Caucasian text".

"The "Caucasian text" of Russian literature, as we see it, is a system of interrelated and interdependent elements, including the concept of literary and mythological archetype and forming its own literary and philosophical "code", which defines it, its text, originality. It represents a dense network of thematic, motivic, imaginative constants with deep internal logic, and therefore constitutes a kind of unified basis of individual literary worlds" [2. P. 25]. "Caucasian text" can be defined as a set of literary texts about the Caucasus, which contain a certain concept. They are in one line with eternal motifs: love, evil, good, peace, war, rivalry, etc., they are "the motives of captivity, vengeance, obedience, honor/ valor, wandering/exile, family hearth, etc., having increased significance, or, in other words, "semantic saturation just for having such deep roots of tradition in Russian literature" [3. P. 297].

We consider the interpenetration and synthesis of the motivic structures of the North Caucasian and Russian literature as a phenomenon that is present in the texts of various writers from different historical and cultural eras. They are manifested in the form of transformed invariants and variants in combination with other motives.

"The motive is seen as a summand constituting a complex formula of the plot". Each motif is a stable set of meanings that were incorporated in it genetically and appeared in the process of historical life [4. P. 204].

\section{Discussion}

\section{Myth-motives as the components of semiotic infrastructure of work about the Caucasus}

Literary works consist of various elements, such as thinking, memory at the level of archetypes, the author's unconscious. All these components determine the unique style 
of the writer, his narrative, which makes him recognizable. Acquaintance with the work brings to the reader the author's point of view, and it, in turn, sets the direction of the whole thought of the work.

The author's vision reflects the reality not completely, but demonstrates the existing reality. The reader complements it yet on his own, interpreting meanings and motives.

It's all about memory at the archetype level. It takes new forms and it is found by the reader and critic in every literary work. According to V.N. Zemskov: "The identification of the creative subject with one or another "archetype" of different levels never means its repetition in its original form, but always entails the literary construction of a new "archetype" on its basis, the transformation of the source material by its own "retelling", paraphrasing those ideological, stylistic, metaphorical contexts that are peculiar to it, and its connection with additional sources and contexts related to it" [5. P. 47].

The concepts of myth, archetype and symbol are the ontology of the work.

The narrative is based on these elements of the literary text; myths, symbols and archetypes give birth to deep levels of understanding of the text, the reader's consciousness independently develops knowledge of the new order.

In this regard, it was found necessary to analyze the plausible folk and mythological basis, which forms the core of the Caucasian works. "Caucasian text" of Russian literature of the first half of the XIX century is more ancient than "Petersburg", "Moscow" and the more "Perm" texts. On thought of W. Shchukin, in the "Caucasian text" there is already a complex of mythologems, "on the basis of which a stable reputation of this place is created in the culture. Inded, the text, if you understand it as defined by Yu. Lotman, B. Uspensky and A. Piatigorsky (their definition was just used by V.N. Toporov at some time), implies the existence of the material manifestation, the boundaries (start and end) and, finally, the well-known semantic isomorphism" [6. P. 279].

Thus, the main proof of the existence of the "Caucasian text", as opposed to a simple text containing information about the Caucasus, is the presence of the encoded in special world cultural signs, with its own existence. Today in literary studies there is no concept of a complete "Caucasian text", and at the apparent distance of solidity, it "on closer examination is not homogeneous, but disintegrating into several independent texts of "lower order" (for example, into "Armenian" and "Georgian" texts, texts about the resort-erotic-fruit the Caucasus, the text about the criminal and rebellious the Caucasus, about the Caucasus as a crossroads of languages and cultures and, of course, the text waiting for the researcher of the Caucasian expat community)" [2. P. 23].

Despite all this, it is obvious that the Caucasus created its own myth and, above all, thanks to literature, that is, it is "literary" and, therefore, has its own "Caucasian" archetype. "This makes it possible, speaking of the "Caucasian text", on the one hand, to "draw" into its orbit much of what has been created in Russian literature from the "Tale of Bygone Years" to the "Underground, or the Hero of Our Time" of V. Makanin, that is to include in its "space" literary content, under which K. Dolinin implies the ideas depicted and expressed by the writers, "concepts and meanings" [2. P. 23].

The literary scholars took up the study of the concept of "myth" quite a long time ago. First of all, the concepts are approached from the cultural side. Myth is one of the most filled semantic categories, which has been studied and analyzed in various aspects since ancient times. And the semantics of the myth is inexhaustible, because with each 
new day it acquires new conjectures that require study. This concept is open and changeable, this is where its uniqueness and versatility lies in.

The most vivid and important historical events of any nation find their reflection in ancient mythology. On the basis of mythology the way of life was evolved: the norms of ethics and the laws of aesthetics were formed. For different ethnic groups, they have become universals.

In addition, the philosophical paradigm depends on myths. They accumulate semantic phenomena within the space-time continuum. The laws of knowledge about man, the noosphere, are based primarily on mythological images of the past. Myth combines the principles and foundations of life, social laws and the basis of morality.

The origin of many modern, well-known genres: drama, poetry, is associated with the rethinking and interpretation of mythical stories. Exploring myths we not only study its structure, but also get additional or new information about many processes in the history of the world.

We appeal to the concept of A. Kofman, "myth-motif”. This term helps us to synthesize and systematize the materials we study in this article. According to A. Kofman mythmotifs "...compose mythological structure of literary text, identifying the symbolic content of myth-motifs, it becomes possible to present a total author's image of the world created on the background of a certain culture" [7. P. 156].

We can conclude that under myth-motifs the repetitive rituals should be understood. Synchronic study of the same motif in a variety of works refers to the notion of mythmotif. In literary works there is a transformation of similar motives, in its process they acquire other semantic signs.

Yu. Kristeva claims: "Speaking of semiotics, we mean production... of models, formalized systems whose structure is isomorphic and similar to the structure of some other system" [8. P. 345]. Thus, myth-motif, operating on replacement, reports integral subjects. It is through them that we can trace the author's narrative, the world and skill he created.

Myth-motif, in turn, consists of separate semantic units - of myth-images able to connect into the solid myth-motif. The formation of myth-motifs through entirety, "poetry is a plurality of relations between elements and relations between relations" [8. P. 346].

Myth-motifs are semiotic infrastructure of works about the Caucasus. Thanks to these concepts, the authors, in particular writers-mountaineers, model the cultural line. It gives a unique opportunity to interpret the author's idea.

\section{Myth-motif space of Khan Girey's tale "Circassian tradition"}

The basis of the story of Khan Giray was the legends of Adyghe folklore. We can definitely name two folk story plots used by the author for its creation; - existed independently in the national epic tale called "Tumbleweed" and the legend of the blood revenge of a young mountaineer, which formed the basis of the poem of M.Yu. Lermontov "Calla" (1830-1831), which the author himself calls the Circassian legend.

Learn: you're miraculously saved

From the bloody hands of murderers, 
To justify the law of the sky

And avenge for the defeated;

And do not belong to you

Your hours, your moments;

You're the gun of vengeance on the land,

The executioner and the victim's Akbulat!

Your father, mother and your brother,

From the hands of the villain dying,

Prayed to the sky about the one:

That at least one dear hand

For them divorced the enemy!

So take my blessings,

Take damask dagger - and go!» -

So spoke brutal Mullah,

And black-eyed Kabardian

Silently, cleaning his dagger,

The lesson of vengeance heed.

$\mathrm{He}$ is young in heart and years,

But, alien to fear, he is ready

The custom of grandfathers and fathers

To fulfill holily over enemies;

He swore - with his hand

To destroy them in the darkness of night [9. P. 246].

Having more or less firmly connected these two legends, the author has made the general subject basis though the dominant position in it has remained behind the fairy tale "Tumbleweed".

The motif of the Motherland occupies a significant place in all the works of Khan Girey, and for his main characters, love for their native land becomes the leading feature of the character, although at first glance it may seem that the dominant motive is still the motive of love, as the story is devoted to the image of lovers Dzhembulat and the Princess, their strong mutual feeling, pure and sublime, their tragic fate. With great skill and talent, with a sense of proportion the writer conducts this line through the whole story. It is this line that makes the work fascinating, gives it a huge impact on the reader. But at the same time, the story deeply reproduces the life of the Adyghe society of that time, the eternal strife in the exploitative elite, clashes and bloody confrontations between the feudal lords. The dukes and nobles in the story are illustrated as the self-willed and jealous lovers of power and tyrants. They hate each other, take up arms against some honest representatives of their class, not giving them the opportunity to defend national interests.

Following the tradition of the Russian romantic school, Khan Girey in his novel recreates a number of interesting images, which, as is common among romantics, mainly reveal the thoughts and feelings that worried the author himself. The positive character of the story is not yet fully objectified, does not live an independent life, but he is always obsessed with great passions, expresses significant social ideas, reveals some characteristic aspects of reality and has a certain cognitive value. 
The image of a romantic hero we see in the name of Dzhembulat. The reader will easily notice that the author sympathizes with the hero and his actions. The attitude toward the hero is largely reveals the views of the writer to surrounding, his ideals and thoughts. Therefore, the study of the temper of the main characters of the story helps to clarify the aesthetic ideas of the author.

The image of Dzhembulat is one of the main successes of the writer. He gets a typical for his time upbringing, given to the Caucasian youth at that time: growing on the traditions of courage, learning to wield weapons and superior to peers as a rider and warrior. If necessary, he is ready to behave in a battle as a dedicated fighter for justice and honor. To resort to deception or falsehood when encountering enemy, he, like Nart heroes, considers vile and dishonest; he is the enemy of a victory obtained in such a cost. Bravery and honesty in the use of weapons are dictated for him by immutable observance of military etiquette. In one of the episodes of the story we find confirmation of what was said. The leaders of the Zhaneys, put out of their patience by the villainy of the Crimean troops in the captured region, decided to cut out the "guests" - the Crimean occupiers. All the messengers of the region unanimously approve this method, the only exception is one Dzhembulat. Even with the worst and cruel enemy, he does not want to fight dishonestly, considering it a sign of cowardice and shame for the national honor.

Tempered in the fire of battles the generation of Caucasians firmly adhered to severe military etiquette, often defended it at the cost of their lives. In this respect Dzhembulat differed little from the others. But among the features of this heroic nature, the writer emphasizes his ardent love for the Fatherland. For his happiness and independence he without hesitation is ready to sacrifice everything, up to life. Without the homeland Dzhembulat does not imagine his existence, outside of it he has no prices. He was born to live in the name and for the good of the Motherland, to serve her faithfully, to be a faithful defender of her honor and freedom. Dzhembulat more than once confirms it in battles in the hour of trouble for the native land, but the writer is not limited to this image, and puts his character in front of other trials that temper him. The rejection of personal happiness in the name of protecting the freedom of the Motherland, a high sense of patriotism, moral beauty, active participation in the national liberation struggle - all this brings together Dzhembulat with the image of Izmail Bey at M.Yu. Lermontov.

Who is this traveler? Russian? No.

$\mathrm{He}$ is in robe, simple beshmet,

Forehead under the shaggy hat;

Dagger sheath, pistol

Are glisting with a poor notch;

And he is tied with a belt,

And saber rings a little on him;

The gun, dangling behind his shoulders,

Turns white in a woolen cover;

And how a mountaineer on the saddle

Cannot be distinguished by me from the Cossacks?

I was not wrong - he is a Circassian!

But the dark color is almost gone

From his cheeks; the snow and blizzard 
And cold of Northern skies,

Of course, washed away the paint of the South,

But you can see that he is Circassian!

Thick eyebrows, eagle eyes,

Eyelashes are long and black,

Movements are fast and free;

He rejected the rite of a foreign land,

Did not shave his beard and mustache,

And a white row of teeth shines,

Like a splash of foam on a coast;

He, how many could, habits, rules

Of his homeland he did not leave... [9. P. 325]

Dzhembulat is not like the self-serving dukes and warks who sell their homeland to the Crimean Khan. If they are willing to speculate for their gain its freedom and have no respect for the suffering of fellows, then brave Dzhembulat raises the Zhaney peasants for the liberation struggle, showing himself a wise and farsighted leader. Despite minor successes, and that subsequently Dzhembulat gets in trouble, he does not regret his actions; he is worried and suffers not from that he was captured and lost in a dungeon, but trampled Motherland and the oppressions perpetrated by the enemy against the tribesmen. When the young man finds out about his release, he says: "Oh, Motherland, my dear Motherland! I'll see you again: I will see you, dear fields, lovely mountains of the Motherland, the dense woods, under whose shadows I grew up, where my carefree, happy youth flowed... I'll breathe more of her air, I will have look at the dear sky! I will dedicate my life again to the good of my Motherland, I will die within it, and my native land will take my ashes" [10. P. 176].

Endowed with chivalrous honor, this hero is selflessly working for the good of the Motherland, lives according to the laws of truth, justice and high humanity, perfectly fulfilling his duty, being at the head of the Zhaney tribe. Unlike people of his class, he becomes a stranger to the ruling self-serving elite, which burns with black envy to his happiness. So cruel dukes punish him. Creating an image of a strong, active and struggling personality, Khan Girey embodied his ideal in it, expressed his thoughts and feelings that worried him at that time. The appeal to the historical past of the native people, to the traditional images of folklore for the writer is not an end in itself. There is a certain connection between the past and the present depicted by him, with the help of such historical parallels he affirms his political credo, recreates the ideal hero who should become an example to follow.

A significant place in the story takes the motive of revenge, which is implemented in the image of the Zhaney Princess. All her actions and actions are guided by one passion she must inherit the helm of her father, become his worthy daughter, support the greatness of the famous princely family. "Revenge, glory and Motherland" - that's what this strong girl worships, for the sake of what she is ready to go to death. This positive image, which does not have a great psychological burden and special national features, was created by the writer in the traditions of Russian romanticism of the early XIX century.

A lot of trouble falls to the share of the girl: the only brother is killed, parents died early, selfish dukes sell the subordinated to her Zhaney tribe to the Crimean Khan. 
Although the Princess meekly withstands all these cruel tests, the atrocities of the Crimean conquerors, committed in her native land, are unbearable for her. Having gathered the elders of the tribe, she calls on them to start a liberation struggle against foreign enslavers, to expel them from their native land. In the misfortunes of her native land, she blames the dukes and the warks, their mutual discord, their indifferent attitude to the fate of the Motherland lead to this.

As Dzhembulat, all her thoughts and deeds the girl submits to the liberation of the Motherland, to the independence and self-existence. Though she cannot fight with arms in her hands along with men, she may willingly give her life for the Motherland at any time, perform her duty in front of it, no matter how hard it may be. It is impossible to consider empty boasting what she tells to her beloved on this subject: "I will not be afraid of battles... not afraid of death... I will join my fate with the fate of the one who in terrible times will defend the Motherland with his breast, I will sacrifice my heart to the one whose hand will reflect the Tatars when they rush to the villages, for the heritage of our tribe. I will not spare my life for the glory of the Motherland" [10. P. 192].

Love to Dzhembulat and her own honor she defends with such passionate conviction that leads to the admiration of Khan, who first sees the real value of human emotions in the face of a loving couple. In contradiction with his cruel nature Khan, convinced of the strength and purity of mutual love of the prisoners, decides to release them and give them the opportunity to get married.

The Princess displays the power of her spirit later also, when losing Dzhembulat. After the tragic death of her beloved, she falls into despair, loses all interest in life, starts thinking about death, considering it the only way out for herself. The Princess decides to commit suicide. But the fate of the only son makes her to think about lots of things and to come back to life.

And although Khan Girey by his origin and social status belonged to the ruling class, he revealed and exposed the cruelty and inhumanity of the feudal lords. They, in his opinion, do not deserve any trust, are not capable of doing a good deed, they are the enemies of truth and righteousness. The author warns that it is necessary to keep as far as possible from their friendship and goodwill. That's how it is said by the mouth of their own henchmen-nobles in everyday conversations: "Here is the horse of duke Kanly also well adorned. He was a sworn enemy of the deceased, and dedicates the memory of his beloved horse...". "Hypocrite!" - one of the spectators interrupted, a man of severe appearance, dressed very simply, but armed well. "What's so surprising? - said his fellow with insulting scorn. - Both friendship and affection of dukes - is only one trick, with which they destroy each other. Duke Kanly ready to swallow Dzhembulat, if only he could, but treats him as a sincere friend... Dukes are real snakes: their affection is poisonous!..." [11. P. 203]

Among the dukes, who are well known to both interlocutors, is Kanly, whose name literally means "bloodthirsty". To achieve his goals, this predatory duke will stop at nothing; he has no pity, no honor, no conscience; he is capable of any meanness and betrayal, regardless of any moral criteria.

One of the most interesting characters of the "Circassian legends" is Teimbulat. At first glance he is a good man; humble, willing to do anything for friendship, for the sake of his own honor. He has a heavy duty - to find the killers of his parents and take revenge 
on them. Knowing the family's tragedy, Kanly is trying to blame their death on Dzhembulat. To convince the young avenger of this, the duke uses any means, but he does not manage to direct him to this false path for a long time.

Teimbulat is wrecked, pushing him to dishonest actions, the love to the Princess - the wife of Dzhembulat. The young man could have won over his feelings if he had a real friend and adviser. But, having planned to eliminate the rival on the way with someone else's hands, Kanly constantly provokes the inexperienced young man, daily inculcating to him the thought that if he does not kill the friend and the instructor, he will never be able to marry the Princess loved by him. Teimbulat is blinded by his love, powerless in front of it and, albeit reluctantly, but agrees with the advice of Kanly and treacherously kills Dzhembulat.

There are people who are able to realize their act with their willpower, forcing themselves to wash away their guilt by finding suitable means for this. Teimbulat is not like that. The crime and his guilt are also compounded by the fact that he commits another heinous act: fraudulently forces the wife of his murdered friend to marry him. Conquered with the help of simulated tears and lamentations, as well as by the price of the blood of his friend "the love and happiness" of Teimbulat did not last long. The fact that evil does not deserve forgiveness, and even tumbleweeds can rip off his mask, Khan Girey skillfully showed in the image of Teimbulat.

Among the motives, traditional for Russian literature about the Caucasus, special attention, in our opinion, deserves the motive of revenge. About it, referring to the world of the Caucasus, said the hero of the Lermontov's poem "Izmail-Bey":

There to hit the enemy - is not a crime;

There is true friendship, but the vengeance is more truthful".

There is good for good, and blood for blood,

And hatred is immeasurable, as love [9. P. 304]

Becoming an indecomposable thematic unit of the work, which is a stable semantic element of the literary text, the motive of vengeance is one of the characterological features involved in the Caucasian "orbit" of the characters of not only Russian but also Caucasian literature. In the works of writers-mountaineers one of the variations of the motive for revenge is often found. The most characteristic universal folk motif is the motif of the search for the father (or revenge for the father), common in Caucasian mythology. The image of the father buried in a crypt appears already in "Circassian legends. The scene in the crypt is written in the tradition of early romanticism. Description of date night of Kanly and Teimbulat resembles the style of S. Kazy-Girey. The crypt in which the deceased father and mother are buried is repeated in the finale of the "Legends": the Princess of Zhaney comes here to commit suicide after the tragic ending, but she is restrained by the thought of her son.

The melodramatic denouement, however, can't hide the steady folk motive of communion of the living to the spirits of deceased ancestors (the sons who come to the tomb of their dead parents to swear, or daughter, who wants to "kill herself" to be reunited with her parents). It goes back to the motif when the hero descends into a dungeon (crypt) and finds his parents (father), with the help of which he is transformed into a magician or wizard. With the known reduction of the mythological story, we find another ancient 
core - ritual. At this level, the same motif, symbolizing in various forms the temporary death and resurrection, meant the rite of initiation of the neophyte. This is how the concept of the most ancient motif is consistently built: rite - myth (folklore work) literary work.

In addition to this motif (which can be roughly described as "the presence of hero in the crypt" or in a dungeon), rather distinct, but significantly transformed by the naive romantic tradition, you can specify another motive - "the vengeance for the father" ("the search for the lost father"). It is universal and most common in Caucasian folklore. The motif is embodied in the scene when the little son of the Zhaney Princess, waving a dagger, chopping watermelons, imagining that in front of him - the killer of his father. At the same time his mother encourages his frame of mind.

Another well-known folk story with "tumbleweed", which squeals on the killer, also gets a literary embodiment in the work of Khan Girey. Having put out of the way his enemy and rival with the help of Teimbulat, the duke marries his widow. At that the "tumbleweed" rolling by is the only witness to the killing that has occurred, throws Teimbulat in a state that squeals him. Vengeance is immediate.

The motive of "revenge for the father" has many variations, most often it is shown in typical childhood games of quickly and wonderfully grown boy - mythological hero, who learns a secret of death of his father from his suffered rival. The hero seeks the mother's consent to take out his father's horse and take out the armor out of dungeon, where they have been hidden for many years. Mother agrees when he sees that a young son can easily fall off Abra stone from the entrance to the tomb (cave) - it's a testament to his magical power (as a result of the initiation of the neophyte).

In "Circassian legends" we meet with the inversion of this motif. The murderer of duke Dzhembulat dies not by the hand of his son, but by his wife, the Zhaney Princess. In this case, there is a literary version of the motif of "revenge for the father".

The work of Khan Girey is interspersed with an episode associated with the image of the sky, when the landlord Dzhembulat and his servant Boren climbed to the top of the mountain.

This image and reasoning of the characters can be regarded as a "pre-symbol" of transcendence. This is not a symbol yet - the disquisitions about the sky are unambiguous, which allows us to talk about it as an allegorical image. Such a "plane" allegorical connotation can probably already be regarded as preceding the symbolic, polysemantic one, through which the literary image gets its further development.

Thus, in the "Circassian legends" we can note the use of some common Caucasian folk motifs, in particular, "revenge for the father" and "the hero's presence in the crypt (cave)". The use of folklore elements at the level of plot - (widespread Caucasian folklore plot about "tumbleweed"), and image-building (the hero-avenger, transforming into the heroine-avenger, as a literary inversion of the image) is noted. It is characteristic that the folk motif "tumbleweed" is still embodied in modern Caucasian literature.

\section{Conclusion}

Appealing to national themes, Russian writers enriched literary motifs in works about the Caucasus, where realism replaced romanticism, that is, images of nature, the way of 
life of Caucasians with the help of romantic categories, and deeply philosophical and realistic representation of the territory of the Caucasus as an integral part of the Russian land.

Enlightenment in the Caucasus, which originated in the depths of the lagged feudal system, even before the formation of bourgeois relations, arose in the early XIX century. Writers-educators of the North Caucasus in General opposed the lagged forms of the feudal system, darkness and ignorance of the people, defended the "natural right" of everyone to freedom and equality, they saw the only means of progress of society in education and enlightenment. A careful reading of the works of writers-mountaineers, such as Shora Nogmov ("History of Adyghe people”), Sultan Kazy Girey ("Azhitugai Valley", "Persian joke"), S. Adil Girey, Khan Girey ("Circassian legends"), Izmail Atazhukin and many others, gives us the opportunity to see their views on the future life of the people. Despite the fact that they were representatives of the ruling class, they at the same time protected the interests of the Caucasus.

At the heart of the literary conflict of the Caucasian writers-educators the motive of the struggle against the system of colonial rule, established by the tsarist government in the Caucasus, is also realized. The view of the enlighteners is a view from the inside, as, being representatives of their people, they saw conservatism and stagnation of the tsarist power in the Caucasus, reflected in their works, based on native folklore, the discontent of workers and class contradictions that took place in the mountain society, and most importantly, they were the first to create the literary world of the hero, who embodied the best features of their contemporaries. In the work of the Sultan Kazy Girey ("Azhitugai Valley"), for example, the traditions of the romantic school are manifested very clearly. Romance permeated the entire text: the character of the hero, description of the nature, style.

Innovative quests should be attributed by the fact that the writers-educators first appealed to the motive of friendship with the Russian neighbours, with Russia. Writersmountaineers were well aware of the difference between the tsarist autocracy and the progressive Russian intelligentsia and could not accept the Russian despotic system of government that was established in the Caucasus.

The main idea laid down in the works of Russian writers and North Caucasian writerseducators about the Caucasus - to cement the concept of literary representation of the Caucasus, the desire to recreate the image of the Caucasus in all its splendor, beauty and truthfulness. Despite the fact that the people were forced to lead a militant lifestyle, the authors of the works saw the price of peace in Caucasus.

Following the truth of life, writers and poets artistically clearly, without missing a single detail, revealed the moral foundations, sanctified by centuries-old traditions, debunking the stereotype that has developed in the imagination of the Russian people about the mountaineers as bandits. The literary "Caucasian texts" of the classics present humanistic studies of Caucasus and its inhabitants.

Summing up, it should be emphasized that the study of literature about Caucasus as an aesthetic, historical, cultural and political phenomenon, in our study from the perspective of Russian and North Caucasian writers - educators, will allow us to get closer to the actual knowledge of the laws of literary development, as well as provide an opportunity to implement a reasonable dialogue of cultures. 


\section{References}

1. Gasparov, M.L. 2000. O russkoj poezii. Analizy. Harakteristiki [About Russian Poetry]. St. Petersburg. Print. (In Russ.)

2. Shul'zhenko, V.I. 2001. Kavkazskij fenomen russkoj prozy (vtoraya polovina XX veka) [Caucasian phenomenon of Russian Prose (second half of the 20th century)]. Pyatigorsk: PyatGFA. Print. (In Russ.).

3. Halizev, V.E. 2000. Teoriya literatury [Theory of Literature]. Moscow: Vysshaya shkola. Print. (In Russ.).

4. Lotman, Yu.M. 2002. Stat'i, po semiotike iskusstva (Seriya «Mir iskusstva») [Articles on Art Semiotics]. St. Petersburg. Print. (In Russ.).

5. Zemskov, V.N. 1993. "Latinoamerikanskaya literatura kak model' kul'tury" [Latin American Literature as a Model of Culture]. Latin America 9: 64-65. Print. (In Russ.).

6. Shchukin, V. 1999. "Moskva i «moskovskij tekst» russkoj kul'tury” [Moscow and Moscow Text of Russian Culture]. Novoe literaturnoe obozrenie 39: 412. Print. (In Russ.).

7. Kofman, A.F. 1997. Latinoamerikanskij hudozhestvennyj obraz mira [Latin American Image of the World]. Moscow. Print. (In Russ.).

8. Kristeva, Yu. 2004. Izbrannye trudy: Razrushenie poetiki [Selected Worcs. Distruction of Poetics]. Rosspen. Print. (In Russ.).

9. Andreev-Krivich, S.A. 1979. Kabardino-cherkesskij fol'klor v tvorchestve Lermontova [KabardinoCircassian Folklore in the Works by Lermontov]. Nal'chik. Print. (In Russ.)

10. Averincev, S.S. 1997. Poetika rannevizantijskoj literatury [Poetics of the Early Byzantine Literature]. Moscow. Print. (In Russ.)

11. Alieva, A.I. 1969. Adygskij nartskij epos [Adyg Narts Epic]. Moscow, Nal'chik. Print. (In Russ.)

(C) Kaziyeva A.M., Pliss A.A., 2019

cc) (i)

This work is licensed under a Creative Commons Attribution 4.0 International License

\section{Article history:}

Received: 24.02 .2019

Accepted: 05.04.2019

Moderator: U.M. Bakhtikireeva

\section{Conflict of interests: none}

\section{For citation:}

Kaziyeva, A.M., and A.A. Pliss. 2019. "Motive as Transhistorical Phenomenon in the Story of the Adyghe-Russian Bilingual-Educator of the Nineteenth Century Khan Girey 'Circassian Legends"”. Polylinguality and Transcultural Practices, 16(2), 276-288. DOI 10.22363/2618897X-2019-16-2-276-288

\section{Bio Notes:}

Almira M. Kazieva is a Doctor in Philology, Professor of the Department of Literature and Pedagogical Technologies of the Philological Education, Pyatigorsk State University. E-mail: k_mika@mail.ru

Anna A. Pliss is a Postgraduate Student of the Department of Domestic and Foreign Literature, Pyatigorsk State University. E-mail: k_mika@mail.ru 


\title{
Мотив как трансисторический феномен в повести адыгско-русского билингва-просветителя XIX в. Хан-Гирея «Черкесские предания»
}

\author{
А.М. Казиева, А.А. Плисс \\ Пятигорский государственный университет \\ Российская Федерация, 357532, Ставропольский край, Пятигорск, пр. Калинина, 9
}

В статье рассматриваются вопросы изучения мотивной структуры «кавказского текста» в произведениях северо-кавказской литературы первой половины XIX в.

В период национального подъема, связанного с декабристским движением, литература пополнилась рядом произведений о Кавказе, написанных Султаном Хан-Гиреем, Султаном Казы-Гиреем, Адиль-Гиреем Кешевым, Костой Хетагуровым и др. Сложилась целая литературная традиция, которая не только поэтизировала кавказский мир, но и старалась изучать его этнографически.

Актуальность статьи связана и с тем обстоятельством, что кавказские мотивы легко прочитываются как в творениях пишущих на русском языке авторов, для которых этот регион является исторической отчизной, так и русских писателей, тяготеющих в собственных художественных пристрастиях к самым разным течениям и стилистическим принципам - от романтических до постмодернистских. Для некоторых из них интерес к мотивам Кавказа является определяющим для всего творчества. Авторы впервые предприняли попытку рассмотреть мотивы, характерные для произведений русской и северо-кавказской литератур о Кавказе в контексте диалога культур.

Ключевые слова: мотивная структура, национальная культура, образ мира, традиционное сознание, картина мира, культурные ценности, кавказско-русское двуязычие, диалог культур

\author{
История статьи: \\ Дата поступления в редакцию: 24.02.2019 \\ Дата принятия к публикации: 05.04.2019 \\ Модератор: У.М. Бахтикиреева
}

Конфликт интересов: отсутствует

\section{Для цитирования:}

Казиева Э.М., Плисс А.А. Мотив как трансисторический феномен в повести адыгско-русского билингва-просветителя XIX века Хан-Гирея «Черкесские предания» // Полилингвиальность и транскультурные практики. 2019. Т. 16. № 2. С. 276-288. DOI 10.22363/2618897X-2019-16-2-276-288

\section{Сведения об авторах:}

Казиева Эльмира Магомедовна - доктор филологических наук, профессор кафедры словесности и педагогических технологий филологического образования Пятигорского государственного университета. E-mail: k_mika@mail.ru

Плисс Анна Александровна - аспирант кафедры отечественной и зарубежной литературы Пятигорского государственного университета. E-mail: k_mika@mail.ru 